\title{
Accidental ingestion of drain cleaner
}

\author{
Torbjørn Ø Pedersen ำ, ${ }^{1}$ Einar Solheim, ${ }^{2}$ Sigbjørn Løes ${ }^{1}$
}

Department of Maxillofacial Surgery, Haukeland University Hospital, Bergen, Norway ${ }^{2}$ Department of Orolaryngology, Førde Central Hospital, Førde, Sogn og Fjordane, Norway

Correspondence to Dr Torbjørn Ø Pedersen; Torbjorn.Pedersen@uib.no

Accepted 13 August 2020

\section{Check for updates}

(c) BMJ Publishing Group Limited 2020. No commercial re-use. See rights and permissions. Published by BMJ.

To cite: Pedersen $\mathrm{T} \varnothing$, Solheim E, Løes S. BMJ Case Rep 2020;13:e237079. doi:10.1136/bcr-2020237079

\section{DESCRIPTION}

A healthy man in his thirties experienced a 'practical joke' during a party when some friends exchanged his alcohol-containing drinking bottle with a potassium hydroxide cleaning agent. The agent, a drain cleaner, had a $\mathrm{pH}$ of 14 according to the producer. The unfortunate consumer managed to spit out most of the liquid after his first sip, but suffered severe etching ulcers on his lips, tongue and palate (figure 1).

He was in a car during the incident and was immediately transported to the hospital. Initially, his airways were secured with orotracheal intubation, but he was extubated the following day as there were no signs of gastric, pharyngeal or laryngeal injury. An antibiotic regimen of penicillin and metronidazole was given to prevent secondary bacterial infection. Also, a mikonazol/hydrocortisone (Dactacort, McNeil Consumer Pharmaceuticals, Fort Washington, Pennsylvania, USA) ointment for his lips and caphosol mouth rinse (EUSA Pharma, Hemel Hempstead, UK) was administered. He was discharged after 5 days with mild opiate analgesics.

The injury caused decreased tongue mobility due to scarring and subsequent difficulties in pronunciation of certain letters. Some improvement was achieved following 4 months of training with a speech pathologist. A minor surgical procedure to increase tongue mobility has been suggested, which the patient has decided to await thus far. He developed a mild opiate addiction after being discharged, but has managed to discontinue his use of opiate analgesics without professional assistance.

Ingestion of alkaline solutions can cause severe injuries due to liquefactive necrosis. Following the initial necrosis and subsequent inflammation, formation of granulation tissue, fibroblastic proliferation

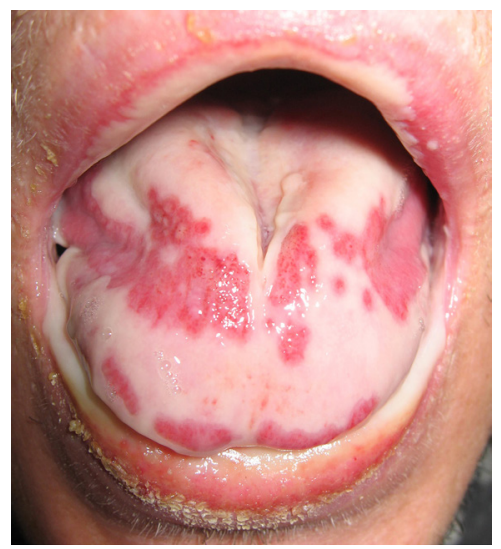

Figure 1 Photo taken after approximately 1 week. The tip of the tongue was etched away and there were signs of focal sloughing, formation of granulation tissue and initial fibrosis.

\section{Patient's perspective}

My primary complaint 4 years after the injury is the reduced mobility of my tongue due to scarring, and I still have minor difficulties in pronunciation. The healing on my lips and palate has been uneventful, and I am happy to recover from my opiate addiction. The relationship with my friends involved was strained by the incident.

\section{Learning points}

Ingestion of alkaline agents can cause severe injury to the oral mucosa.

- Care should be taken to keep drain cleaners away from children, but also from friends.

and scarring may follow, depending on the severity of the injury. These injuries can be classified similar to burns of the skin according to the depth of the damage. The pharynx and gastrointestinal tract is most commonly affected, but also injuries to the mouth have been described, in particular in children. ${ }^{1}$ In fact, the majority of patients ingesting caustic agents are children, and a peak incidence is found at 2 years old. ${ }^{2}$ Severe scarring in growing patients may result in perioral contractions and potential growth disturbances, but also for adult patients, scarring can lead to functional problems. Affected areas may be more susceptible to malignant transformation and regular follow-up is recommended. ${ }^{3}$

Contributors TØP consulted the patient, drafted the manuscript and approved the final version. ES assessed and treated the patient, critically revised the manuscript and approved the final version. SL consulted the patient, critically revised the manuscript and approved the final version.

Funding The authors have not declared a specific grant for this research from any funding agency in the public, commercial or not-for-profit sectors.

Competing interests None declared.

Patient consent for publication Obtained

Provenance and peer review Not commissioned; externally peer reviewed.

ORCID iD

Torbjørn Ø Pedersen http://orcid.org/0000-0001-9463-3076

\section{REFERENCES}

1 Ryan F, Witherow H, Mirza J, et al. The oral implications of caustic soda ingestion in children. Oral Surg Oral Med Oral Pathol Oral Radiol Endod 2006:101:29-34.

2 Rafeey M, Ghojazadeh M, Sheikhi S, et al. Caustic ingestion in children: a systematic review and meta-analysis. J Caring Sci 2016;5:251-65.

3 Andreoni B, Marini A, Gavinelli M, et al. Emergency management of caustic ingestion in adults. Surg Today 1995;25:119-24. 
Copyright 2020 BMJ Publishing Group. All rights reserved. For permission to reuse any of this content visit https://www.bmj.com/company/products-services/rights-and-licensing/permissions/

BMJ Case Report Fellows may re-use this article for personal use and teaching without any further permission.

Become a Fellow of BMJ Case Reports today and you can:

- Submit as many cases as you like

Enjoy fast sympathetic peer review and rapid publication of accepted articles

Access all the published articles

Re-use any of the published material for personal use and teaching without further permission

Customer Service

If you have any further queries about your subscription, please contact our customer services team on +44 (0) 2071111105 or via email at support@bmj.com.

Visit casereports.bmj.com for more articles like this and to become a Fellow 